\title{
AKIBAT HUKUM PEMBATALAN AKTA KELAHIRAN TERHADAP ANAK
}

\section{THE LAWFUL CONSEQUENCES OF BIRTH CERTIFICATE ON CHILDREN ABROGATION}

\author{
Natasya Immanuela Sandjojo
}

Faculty of Law Airlangga University

JL. Dharmawangsa Dalam Selatan, Airlangga, No. 4-6, Surabaya, East Java, Indonesia Telp./Fax: +62-623-15023151 Email: sasyasandjojo@gmail.com

Submitted: Nov 01, 2017; Reviewed: Dec 27, 2017; Accepted: Dec 30, 2017

\begin{abstract}
Abstrak
Penelitian akibat hukum pembatalan akta kelahiran terhadap anak bertujuan untuk mengetahui akibat hukum yang berpengaruh terhadap anak, serta meninjau dari penetapan dan putusan hakim di pengadilan yang berperan dalam pembatalan akta kelahiran. Penelitian ini memaparkan pentingnya akta kelahiran karena masih rendahnya kesadaran masyarakat untuk melakukan pencatatan kelahiran. Penelitian menggunakan penelitian yuridis normatif, yang menghadapi isu hukum dengan proses menemukan aturan, prinsip, serta doktrin hukum yang berkaitan dengan isu hukum, dengan metode deduktif, berawal dari hal yang umum lalu menghasilkan jawaban yang bersifat khusus dan sah. Berdasarkan hasil penelitian, bahwa pembatalan akta kelahiran membawa akibat hukum yang besar bagi anak, khususnya status dan kedudukan anak, serta hak alimentasi yang dalam penelitian ini dicantumkan beberapa contoh penetapan dan putusan pengadilan tentang pembatalan akta kelahiran.
\end{abstract}

Kata Kunci: Akibat Hukum; Akta Kelahiran; Pembatalan akta kelahiran

\begin{abstract}
Research due to the law on the abrogation of birth certificates against children aims to know the effect of law affecting the child, as well as review of the determination and judgment in court that play a role in the birth certificate abrogation. This research describes the importance of birth certificate because of the low public awareness to perform birth registration. The study uses normative juridical research, which faces legal issues with the process of discovering legal rules, principles, and legal doctrines, with deductive methods, starting from the general thing and then generating specific and legitimate answers. Based on the results of the study, that the abrogation of birth certificate brings great lawful consequences for the child, especially the status and position of the child, as well as the right of alimentation, which in this study included some examples of determination and court decision about the birth certificate abrogation.
\end{abstract}

Keywords: Birth Certificate; Birth Certificate Abrogation; Lawful Consequences 


\section{PENDAHULUAN}

Perkembangan zaman dan kemajuan ilmu teknologi sudah pasti mempengaruhi adat yang hidup di Indonesia, adat kebiasaan mulai berubah ke arah yang lebih bebas, yang paling mencolok adalah dalam hubungan antara laki-laki dan perempuan. Hubungan yang ditempuh dengan komitmen untuk membangun suatu keluarga dilindungi oleh agama dan hukum dalam perkawinan, di Indoensia perkawinan dilindungi oleh hukum dengan Undang-Undang Perkawinan Nomor 1 tahun 1974. Perkembangan zaman ini menyebabkan banyaknya pasangan laki-laki dan perempuan yang mengambil keputusan untuk melakukan hubungan layaknya suami istri tanpa adanya ikatan perkawinan, dan hal ini jelas tidak dapat dilindungi oleh hukum, salah satunya apabila pasangan tersebut memiliki anak dari hubungan tersebut.

Anak merupakan amanah dan anugerah dari Tuhan Yang Maha Esa yang dalam dirinya melekat harkat dan martabat sebagai manusia seutuhnya. Kedudukan anak ditentukan dari keabsahan perkawinan orangtuanya, dimana anak tersebut lahir dalam sebuah perkawinan yang sah sebagai anak sah atau anak tersebut lahir di luar perkawinan yang sah sebagai anak luar kawin. Berdasarkan Un-
dang-Undang Perkawinan Pasal 2 suatu perkawinan dianggap sah dan dilindungi hukum apabila perkawinan tersebut dilaksanakan secara agama dan dicatatkan sesuai dengan peraturan perundangundangan ${ }^{1}$. Pentingnya penca-tatan perkawinan seringkali tidak disadari oleh masyarakat, sehingga berpengaruh terhadap kedudukan anak yang terlahir dalam hubungan di luar perkawinan, sesuai dengan Undang-Undang Perkawinan Pasal 43, anak luar kawin hanya memiliki hubungan perdata dengan ibu dan keluarga ibunya.

Pernyataan yang ada di dalam Undang-Undang Perkawinan Pasal 43 tersebut kembali menjadi keresahan di masyarakat karena dirasa ada ketidakadilan bagi pihak ibunya, dimana ayahnya dilepaskan tanggung jawab dari anaknya sehingga menghasilkan putusan Mahkamah Konstitusi Nomor 46/PUUVIII/2010, ${ }^{2}$ yang menegaskan bahwa anak yang lahir di luar perkawinan mempunyai hubungan perdata dengan ibunya dan keluarga ibunya serta dengan laki-laki sebagai ayahnya yang dapat dibuktikan ber-

\footnotetext{
${ }^{1}$ Undang-Undang Nomor 1 tahun 1974 tentang Perkawinan

${ }^{2}$ Putusan Mahkamah Konstitusi Nomor 46/PUU-VIII-2010,

http://www.bphn.go.id/data/documents/putusan _46-puu-viii-2010_(perkawinan).pdf, diakses pada tanggal 4 September 2017, 12.15 WIB
} 
dasarkan ilmu pengetahuan dan teknologi dan/atau alat bukti lain menurut hukum mempunyai hubungan darah, termasuk hubungan perdata dengan keluarga ayahnya. Hal ini menimbulkan pro dan kontra, hingga MUI (Majelis Ulama Islam) mengeluarkan Fatwa Nomor 11 Tahun 2012, bahwa ${ }^{3}$ :

Anak hasil zina tidak mempunyai hubungan nasab, wali nikah, waris dan nafkah dengan laki-laki yang menyebabkan kelahirannya dan hanya mempunyai hubungan nasab, waris, dan nafkah dengan ibunya dan keluarga ibunya. Namun demikian ditegaskan, bahwa anak hasil zina tersebut tidak menanggung dosa perzinaan yang dilakukan oleh orang yang mengakibatkan kelahirannya. Siapa anak zina itu ditegaskan, adalah anak yang lahir sebagai akibat dari hubungan badan di luar perkawinan yang sah menurut ketentuan agama. Sebagai bentuk wujud tanggung jawab, menurut fatwa tersebut, pemerintah berwenang menjatuhkan hukuman kepada laki-laki pezina yang mengakibatkan lahirnya anak dengan mewajibkan kepadanya untuk mencukupi kebutuhan hidup anak tersebut dan memberikan harta setelah ia meninggal dunia melalui wasiat wajibah. Hukuman dimaksud bertujuan untuk melindungi anak, bukan untuk mensahkan hubungan nasab antara anak tersebut dengan ayah biologisnya atau laki-laki yang mengakibatkan kelahirannya.

\footnotetext{
${ }^{3}$ Rachmadi Usman.(2014). 'Prinsip Tanggung Jawab Orangtua Biologis Terhadap Anak Di Luar Perkawinan', Jurnal Konstitusi Vol.11 no. 1 , Maret :190
}

Anak sebagai generasi penerus bangsa berhak medapatkan perlindungan dari negara, perlindungan yang diberikan oleh negara ini dilindungi oleh hukum dan diberikan tanpa diskriminasi, sesuai dengan prinsip yang terdapat UndangUndang Nomor 17 Tahun 2016 tentang Perlindungan Anak yang dibentuk pemerintah agar hak-hak anak dapat diimplementasikan di Indonesia. ${ }^{4}$ Salah satu bentuk perlindungan anak dari negara yaitu dengan memberikan anak sebuah identitas diri yang dituangkan di dalam akta kelahiran. Akta kelahiran sebagai identitas diri seorang anak juga menjadi salah satu syarat dimana anak tersebut nantinya akan diberikan Nomor Induk Kependudukan di saat anak tersebut sudah dewasa. Adanya Putusan Mahkamah Konstitusi Nomor 46/PUU-VIII/2010 sebenarnya mempertegas berlakunya Undang-Undang Perlindungan Anak terhadap anak luar kawin, yang juga mempunyai hak yang sama dengan anakanak yang lain, berkaitan dengan hak akan identitas, nama, dan hak untuk mengetahui orangtuanya yang hanya dapat

\footnotetext{
${ }^{4}$ Sasmiar.(2012). 'Kedudukan Hukum Anak Tidak Sah Sebelum Dan Setelah Putusan Mahkamah Konstitusi Nomor 46/PUUVIII/2010', Jurnal Ilmu Hukum Universitas Jambi Vol.3 No.1, September :67
} 
dibuktikan dengan sebuah akta kelahiran ${ }^{5}$, dimana akta kelahiran adalah salah satu bukti identitas diri seorang anak, hal ini ditegaskan di dalam Undang-Undang Perkawinan pasal 55 ayat (1). Dengan ketiadaan kepemilikan akta kelahiran ini, menyebabkan ketidakjelasan identitas anak, yang akan membawa sejumlah implikasi seperti diskriminasi, tidak memiliki akses terhadap pelayanan dasar pendidikan dan kesehatan, rawan menjadi korban perdagangan manusia, mudah dijadikan pekerja anak, rawan menjadi korban kejahatan seksual, dan lain-lain. Rendahnya kepemilikan akta kelahiran menunjukkan kepedulian tentang hak anak oleh orang tua dan pemerintah perlu ditingkatkan. ${ }^{6}$

Dalam penerbitan akta kelahiran memiliki beberapa persyaratan dokumen yang harus dipenuhi untuk memastikan bahwa informasi yang akan tercatat di dalam akta kelahiran menjadi identitas diri

${ }^{5}$ Djumikasih.(2013). 'Implikasi Yuridis Putusan MK Nomor 46/PUU-VIII/2010 Terhadap Akta Kelahiran Anak Luar Kawin', Jurnal Arena Hukum Universitasi Brawijaya, Vol.6 No.2, Agustus : .212

${ }^{6}$ Kementerian Koordinator Bidang Pembangunan Manusia dan Kebudayaan Republik Indonesia.(2017). 'Kemenko PMK Dorong Agenda Prioritas Kepemilikan Akta Kelahiran', Siaran Pers Nomor : 28/HumanPMK/III/2017 <https://www.kemenkopmk.go.id/sites/default/ files/pengumuman $/ 28 \% 20$ Siaran $\% 20$ Pers $\% 20$ Kemen-

ko\%20PMK\%20Dorong\%20Kepemilikan\%20 Akta\%20Kelahiran.pdf>, diakses pada tanggal 7 Oktober 2017 seorang anak yang bersifat autentik. Namun masih banyak masalah yang menyangkut akta kelahiran sehingga menimbulkan banyak gugatan serta permohonan untuk membatalkan sebuah akta kelahiran, misalnya pemalsuan identitas dalam akta kelahiran. Pembatalan akta kelahiran ini dapat dilakukan dengan adanya putusan pengadilan yang telah memperoleh kekuatan tetap, ${ }^{7}$ sehingga dirasakan pentingnya sebuah akta kelahiran serta mengetahui akibat hukum pembatalan akta kelahiran terhadap anak.

\section{Rumusan Masalah}

1. Apa urgensi akta kelahiran bagi anak menurut undang-undang?

2. Apa akibat hukum pembatalan akta kelahiran terhadap anak?

\section{Tujuan Penelitian}

1. Untuk menganalisis urgensi akta kelahiran sebagai bukti dalam kedudukan hak anak.

2. Untuk mengalisis akibat hukum yang berdampak dari pembatalan akta kelahiran.

${ }^{7}$ Peraturan Presiden Republik Indonesia Nomor 25 Tahun 2008 tentang Persyaratan dan Tata Cara Pendaftaran Penduduk dan Pencatatan Sipil Pasal 102 


\section{METODE PENELITIAN}

Tipe Penelitian

Penelitian ini menggunakan penelitian hukum. Penelitian hukum adalah suatu proses untuk menemukan aturan hukum, prinsip-prinsip hukum, maupun doktrindoktrin hukum guna menjawab isu hukum yang dihadapi. ${ }^{8}$ Penelitian bersifat normatif dengan pendekatan perundangundangan, konseptual dan kasus.

\section{Sumber Bahan hukum}

Bahan hukum yang digunakan dalam penelitian ini sebagai berikut:

\section{Bahan Hukum Primer}

Bahan hukum yang bersifat autoritatif yang artinya memiliki otoritas.

2. Bahan Hukum Sekunder

Semua publikasi tentang hukum yang bukan merupakan dokumen-dokumen resmi ${ }^{9}$

\section{Teknik Pengumpulan Data}

Pengumpulan bahan hukum dilakukan melalui studi pustaka dengan inventarisasi, klasifikasi, dan sistematisasi. Inventarisasi dengan mengumpulkan bahan-bahan hukum yang berkaitan dengan hak perlindungan anak terkait dengan pencatatan kelahiran. Setelah itu, bahan hukum tersebut

\footnotetext{
${ }^{8}$ Peter Mahmud Marzuki.(2010). Penelitian Hukum, Cetakan ke VI, Jakarta: Kencana, HIm. 35.

${ }^{9}$ Ibid., Hlm. 141.
}

diklasifikasikan dengan cara memilahmilah bahan hukum sesuai dengan rumusan masalah yang tersebut di atas. Untuk lebih mempermudah dan memahami bahan hukum tersebut maka dipelajari dengan cara sistematik.

\section{Analisis Data}

Dalam tipe penelitian yuridis normatif, maka metode yang digunakan adalah metode deduktif. Berawal dari hal yang bersifat umum, dalam hal ini adalah peraturan perundang-undangan, doktrin, serta teori-teori dalam literatur yang bersifat umum, kemudian diterapkan pada rumusan masalah yang menghasilkan jawaban yang bersifat khusus untuk memperoleh jawaban yang sahih/valid digunakan penafsiran otentik dan penafsiran sistematis. Penafsiran otentik adalah penafsiran yang pasti terhadap suatu arti kata yang ditentukan dalam peraturan perundang-undangan itu sendiri. Sedangkan pengertian dari penafsiran sistematis adalah penafsiran dengan cara melihat atau memperhatikan susunan pasal yang berhubungan dengan pasalpasal yang lainnya yang ada di dalam undang-undang itu sendiri maupun dengan pasal-pasal lain dari undang-undang yang lain untuk memperoleh pengertian yang lebih pasti. 


\section{ANALISIS DAN PEMBAHASAN}

\section{Akta Kelahiran Sebagai Bentuk Pengakuan dan Perlindungan Hukum Dari Negara}

Anak-anak yang lahir di Indonesia sebagai generasi penerus bangsa berhak mendapatkan perlindungan hukum dan pengakuan dari negara. Salah satu upaya pengakuan dan perlindungan hukum yang diberikan oleh negara dituangkan di dalam Undang-Undang Perlindungan Anak juga dalan Undang-Undang Hak Asasi Manusia. Melalui Undang-Undang Perlindungan Anak, ditegaskan dalam Pasal 1 ayat (2) bahwa perlindungan anak adalah segala kegiatan untuk menjamin dan melindungi anak dan hak-hak agar dapat hidup, tumbuh, berkembang, dan berpartisipasi secara optimal sesuai dengan harkat dan martabat kemanusiaan serta mendapat perlindungan dari kekerasan dan diskriminasi. Perlindungan anak dianggap penting, tidak hanya dalam proses peradilan namun juga mencakup lingkup yang luas seperti perlindungan hukum terhadap berbagai kebebasan anak dan hak asasi manusia sebagai anak serta kepentingan yang berhubungan dengan kesejahteraan anak. ${ }^{10}$

${ }^{10}$ Waluyadi.2009. Hukum Perlindungan Anak, Banudng: Mandar Maju, Hlm.1.
Perlindungan anak yang ada di negara ini dilindungi oleh hukum, dengan demikian kepastian hukum perlu diusahakan demi kelangsungan kegiatan perlindungan anak dan mencegah penyelewengan yang membawa akibat negatif yang tidak diinginkan dalam pelaksanaan perlindungan anak. ${ }^{11}$ Salah satu perlindungan pertama yang diberikan oleh negara adalah dengan memberikan identitas kepada anak melalui pencatatan kelahiran dalam bentuk akta kelahiran, ada 3 alasan pentingnya pencatatan kelahiran yaitu :

1. Pencatatan kelahiran adalah pengakuan formal mengenai keberadaan seseorang anak secara individual terhadap negara dan status anak dalam hukum.

2. Pencatatan kelahiran adalah elemen penting dari perencanaan nasional untuk anak-anak, memberikan dasar demografis agar strategis yang efektif dapat dibentuk.

3. Pencatatan kelahiran adalah cara untuk mengamankan hak anak lain misalnya identifikasi anak sesudah berperang, ditelantarkan atau diculik agar anak dapat mengetahui orang tuanya (khususnya jika lahir di luar nikah), sehingga mereka mendapat akses pada sarana atau prasaran dalam perlindungan negara dalam batas usia hukum (misal-

\footnotetext{
${ }^{11}$ Arif Gosita.1989. Masalah Perlindungan Anak, Jakarta: Akademi Pressindo, Hlm.19.
} 
nya: pekerjaan, rekruitmen ABRI, dalam sistem peradilan anak) serta mengurangi atau kemungkinan penjualan bayi. $^{12}$

Akta kelahiran ini dibuat dan dikeluarkan oleh Dinas Kependudukan dan Catatan Sipil (dispendukcapil), dimana dispendukcapil adalah suatu lembaga yang diusahakan oleh pemerintah yang ditugaskan untuk memelihara daftardaftar atau catatan-catatan guna pembuktian status atau peristiwa-peristiwa penting bagi para warga negara seperti kelahiran, perkawinan, kematian. ${ }^{13}$ Volmar juga memberikan penjelasan tentang lembaga catatan sipil adalah suatu lembaga yang diakan oleh penguasa/ pemerintah yang dimaksud membukukan selengkap mungkin karena itu memberikan kepastia sebesar-besarnya tentang semua peristiwa yang penting bagi status keperdataan seseorang termasuk perkawinan, kelahiran, perceraian, dan kematian. ${ }^{14}$

Akta kelahiran sebagai salah satu bentuk pengakuan dan juga perlindungan dari negara di mana anak tersebut

\footnotetext{
${ }^{12}$ Daly Erni. 1999. "Kajian Impelementasi Peraturan Perundang-undangan Dalam Hal Pembuatan Akta Kelahiran", Laporan Penelitian Depok, Hlm.2.

${ }^{13}$ Victor M.Situmorang dan Cormentyna Sitanggang. 1991. Aspek Hukum Akta Catatan Sipil Di Indonesia, Jakarta: Sinar Grafika, Hlm.10.

${ }^{14}$ Volmar. 1989. Pengantar Studi Hukum Perdata, Jilid I, Jakarta: Rajawali, Hlm.37.
}

dilahirkan, ditegaskan di dalam UndangUndang Perlindungan anak Pasal 27 di mana identitas anak berupa akta kelahiran harus diberikan sejak kelahirannya dan juga kembali ditegaskan dalam UndangUndang Nomor 24 Tahun 2013 tentang Perubahan Atas Undang-Undang Nomor 23 Tahun 2006 tentang Administrasi Kependudukan Pasal 27 dikatakan bahwa setiap kelahiran wajib dilaporkan kepada instansi pelaksana setempat dan pejabat pencatatan sipil akan menerbitkan kutipan akta kelahiran untuk anak tersebut. Dalam perspektif Convention on the Rights of the Child, negara harus memberikan pemenuhan hak dasar kepada setiap anak, dan terjaminnya perlindungan atas keberlangsungan, tumbuh kembang anak misalnya di bidang kesehatan dan pendidikan termasuk hak atas nama dan kewarganegaraan. Hak atas nama dan kewarganegaraan merupakan hak dasar yang melekat pada setiap anak yang wajib diberikan negara. Identitas anak diberikan segera setelah anak itu lahir secara gratis. Negara wajib memberikan identitas anak sebagai bentuk pengakuan dan bukti hukum bahwa seseorang itu ada serta untuk mengenalinya diperlukan nama. Sementara kewarganegaraan merupakan alat bukti hukum bahwa seseorang adalah warga negara yang akan terkait dengan status, 
perlindungan dan hak serta kewajiban anak yang bersangkutan. ${ }^{15}$

Disadari rendahnya tingkat kesadaran masyarakat akan pentingnya akta kelahiran, banyak permasalahan yang terjadi berpangkal dari ketidakjelasan akta kelahiran seorang anak yang dapat mengakibatkan manipulasi identitas anak. Semakin tidak jelas identitas seorang anak, maka semakin mudah terjadi eksploitasi terhadap anak seperti anak menjadi korban perdagangan bayi dan anak, tenaga kerja dan kekerasan. Rendahnya kesadaran akan pentingnya akta kelahiran ini berdasarkan data dimana pada bulan Maret 2017, jumlah anak yang tidak memiliki akta kelahiran di Indonesia kurang lebih 20 juta anak. Hal ini terjadi karena hambatan-hambatan yang dikeluhkan oleh masyarakat seperti hambatan jarak, biaya, dan juga proses waktu yang memakan waktu cukup lama. ${ }^{16}$

\footnotetext{
${ }^{15}$ Davit Setyawan. 2014. Pemenuhan Hak Anak Atas Akta Kelahiran Merupakan Bagian Dari Hak Sipil Yang Harus Dilindungi Konstitusi, $15 \quad$ Februari 2014 http://www.kpai.go.id/artikel/pemenuhan-hakanak-atas-akta-kelahiran-merupakan-bagiandari-hak-sipil-yang-harus-dilindungikonstitusi/, diakses tanggal 15 Agustus 2017 jam 13.05

${ }^{16}$ Suara Pembaharuan, Hampir 20 Juta Anak Indonesia Belum Memiliki Akte Kelahiran, http://sp.beritasatu.com/home/hampir-20-jutaanak-indonesia-belum-miliki-aktekelahiran/118592, diakses tanggal 25 Agustus 2017 jam 12.20 WIB
}

Dapat disimpulkan dari pembahasan di atas, bahwa akta kelahiran mempunyai peran penting di dalam kehidupan seseorang, selain itu akta kelahiran memberikan perlindungan terhadap anak yang lahir di suatu negara, dengan pencatatan kelahiran anak tersebut maka negara dapat mengkalkulasi pertumbuhan penduduk serta memenuhi hak-hak yang memang menjadi hak anak tersebut khususnya pada anak-anak yang tidak diketahui identitasnya, mereka sangat membutuhkan pencatatan kelahiran sehingga dapat dilindungi oleh negara.

\section{Akta Kelahiran Sebagai Kepastian Hukum Kedudukan Anak}

Kelahiran seorang anak pasti terkait dengan hubungan antara laki-laki dan perempuan yang disebut sebagai perkawinan, di mana menurut ahli hukum Asser, Scholten, Melis, Wiarda, Pitlo memberikan pendapat mengenai perkawinan yaitu suatu persekutuan antara seorang laki-laki dan seorang wanita yang diakui oleh negara untuk bersama (bersekutu) yang kekal. ${ }^{17}$ Sahnya sebuah perkawinan di dalam suatu negara diwujudkan dalam bentuk peraturan-peraturan yang mengatur tentang perkawinan. Di Indonesia, sahnya sebuah perkawinan diatur dalam Undang-

${ }^{17}$ Titik Triwulan Tutik. 2006. Pengantar Hukum Perdata, Jakarta:Prestasi Pustaka, Hlm. 56. 
Undang Perkawinan dengan syarat dilakukan menurut hukum agamanya dan juga dicatatkan menurut peraturan yang belaku, meskipun hal ini tidak terlihat terlalu esensial namun akan berpengaruh besar pada anak yang lahir dari pasangan laki-laki dan perempuan yang ikatan perkawinannya sah maupun tidak sah.

Dalam hukum Indonesia, akibat dari sahnya perkawinan atau tidak berperangaruh terhadap kedudukan anak, kedudukan anak ini dibedakan menjadi 2 (dua) sebagai anak yang lahir dalam perkawinan yang sah atau sering disebut anak sah dan anak yang lahir di luar perkawinan yang sah atau sering disebut anak luar kawin. Namun dalam perlindungan anak, negara tidak melihat status anak sah ataupun anak luar kawin, semua anak berhak atas suatu akta kelahiran yang merupakan salah satu hak anak yang paling awal. Satu-satunya alat bukti yang dapat membuktikan kedudukan seseorang dalam struktur kekeluargaan adalah melalui akta kelahiran, selain itu akta kelahiran juga dijadikan jati diri/membuktikan dirinya bahwa ia adalah ahli waris yang sah dari seseorang pewaris. Jati diri itu dapat diperoleh sebab suatu akta kelahiran akan mencantumkan dengan jelas tentang hari, tanggal, bulan dan tahun kelahiran serta ditegaskan pula nama orang tuanya yang melahirkan dan juga hubungan orang tuanya, apakah sebagai suami-istri yang sah atau tidak. ${ }^{18} \mathrm{Di}$ samping itu, sesuai dengan UndangUndang Perkawinan pasal 55 ayat (1) akta kelahiran yang autentik dan dikeluarkan oleh Pejabat yang berwenang merupakan salah satu pembuktian asal usul seorang anak. Akta kelahiran sebagai bukti yang kuat dan sah untuk menentukan identitas diri seseorang juga dipertegas oleh parah ahli hukum, bahwa:

Victor M. Situmorang dan Cormentya Sitanggang

"Bagaimanakah anak tersebut membuktikan bahwa dianya (anak asuh) anak dari orang tuanya. Malah tersebut dapat diatas dengan baik apabila anak tersebut dapat menunjukkan bukti-bukti yang kuat dan autentik bahwa dirinya adalah anak sah orang tuanya. Sebab bukti yang sah tentunya dalah suatu bukti tertulis yang autentik yang menerangkan tentang suatu hal, agar hal tersebut mempunyai dasar kekuatan hukum yang pasti dan kuat Demikian pula dengan peristiwa kelahiran seseorang, peristiwa kelahiran itu perlu mempunyai bukti tertulis dan autentik, karena untuk membuktikan identitas seseorang yang pasti dan sah adalah dapat kita lihat dari akta kelahirannya yang dikeluarkan oleh suatu lembaga yang berwenang mengeluarkan akta tersebut." 19

\footnotetext{
${ }^{18}$ Victor M.Situmorang dan Cormentyna Sitanggang, Op.cit., Hlm.39-40.

${ }^{19}$ Ibid., Hlm. 40.
} 


\section{J. Satrio}

"Akta kelahiran memang membuktikan bahwa seorang anak yang namanya tercantum di dalamnya adalah anak dari orang yang disebutkan dalam akta kelahiran yang bersangkutan, paling tidak dari seorang perempuan yang melahirkan anak itu, yang namanya tercantum di sana. Di samping itu, akta kelahiran juga mencantumkan hari dan tanggal lahir anak itu. Saat kelahiran sang anak inilah yang dihubungkan dengan status perkawinan dari perempuan yang melahirkan anak tersebut, hal ini menentukan pula hubungan anak itu dengan suami dari perempuan yang melahirkannya." 20

Pendapat para ahli di atas menunjukkan bahwa suatu bukti kuat yang menentukan identitas seorang anak, siapa orangtuanya dan kapan ia dilahirkan adalah satu-satunya melalui akta kelahiran yang dikeluarkan oleh dispendukcapil. Akta kelahiran dianggap sebagai bukti yang kuat karena merupakan bukti tertulis yang autentik, dan dapat diingat kembali bahwa salah satu alat pembuktian dalam Pasal 1866 BW adalah bukti tertulis, dan di pasal 1867 BW juga ditegaskan bawah pembuktian dengan tulisan dilakukan dengan tulisan autentik atau tulisan di bawah tangan. Di mana akta kelahiran merupakan salah satu akta autentik, sehingga akta kelahiran merupakan salah

\footnotetext{
${ }^{20}$ Juswito Satrio. 2000. Hukum Keluarga Kedudukan Anak Dalam Undang-Undang, Bandung: Citra Aditya Adi, Hlm. 83-84.
}

satu alat pembuktian yang kuat dan mempunyai dasar hukum yang pasti.

Berkaitan dengan masalah-masalah pembatalan akta kelahiran yang timbul di Indonesia, maka ini menjadikan pertanyaan, apakah keputusan yang diberikan oleh Mahkamah Konstitusi Nomor 18/PUU-XI/2013 merupakan hal yang tepat, karena dengan adanya putusan MK ini maka ada kewenangan yang beralih dari Pengadilan Negeri kepada dispendukcapil. Dari pertimbangan hukum dan putusan Mahkamah Konstitusi, diperlukan kehati-hatian oleh dispendukcapil dalam menerbitkan akta kelahiran yang sudah terlambat 1 tahun setelah kelahirannya, mengingat banyak hal yang dapat terjadi dalam 1 tahun, dan hal ini berkaitan dengan kedudukan anak. Verifikasi dokumen sangat diperlukan dalam pendaftaran akta kelahiran yang terbilang terlambat dari seharusnya, di mana seharusnya pengadilan negeri mendapat kewenangan untuk memanggil saksi-saksi tentang keabsahan dan kedudukan seorang anak, namun dengan putusan ini kewenangan dilimpahkan pada dipendukcapil yang tidak memiliki kewenangan untuk menguji kebenaran materiil. ${ }^{21}$ Per-

\footnotetext{
${ }^{21}$ Trias Palupi Kurnianingrum. 2014. 'Implikasi Putusan Mahkamah Konstitusi No 18/PUUXI/2013 Terhadap Penerbitan Akta Kelahiran' Jurnal Ilmiah Hukum Negara Hukum SETJEN DPR RI Vol.5 no.1 Juni :.72
} 
timbangan hakim dalam Putusan MK di atas menyetujui adanya penghapusan Pasal 32 ayat (2) Undang-Undang Administrasi Kependudukan dengan alasan bahwa isi pasal ini bertentangan dengan Undang-Undang Dasar Negara Republik Indonesia 1945 Pasal 27 ayat (1), 28D ayat (1), dan lebih khusus pasal 28D ayat (4), seharusnya hakim bisa menelaah lebih lanjut bahwa keterlambatan dalam pencatatan kelahiran yang mencapai 1 tahun lamanya dapat menjadi resiko yang besar.

Kurangnya kehati-hatian dalam verifikasi dokumen dalam pencatatan kelahiran dapat menjadi penyebab kasus seperti kasus putusan Mahkamah Agung No.348K/TUN/2016, di mana verifikasi tentang dokumen yang tidak dilakukan dengan teliti maka dapat mengakibatkan kesalahan terhadap identitas seseorang dan merugikan pihak lain. Hal ini perlu kembali diperhatikan oleh pemerintah, apakah keputusan untuk menghapuskan peraturan sudah tepat, dikarenakan dispendukcapil tidak mempunyai kewenangan untuk memeriksa dan memanggil saksi-saksi berkaitan dengan pendaftaran akta kelahiran, sehingga kebenaran dari dokumen-dokumen yang dibawa untuk pencatatan kelahiran tidak terjamin. J. Satrio berpendapat bahwa:

"Akta kelahiran membuktikan bahwa seorang anak yang namanya tercan- tum di dalamnya adalah keturunan dari orang-orang yang disebutkan di dalamnya. Namun, akta kelahiran yang dikeluarkan oleh Kantor Catatan Sipil belum cukup untuk membuktikan siapa ibu si anak, karena pencatatan kelahiran dilakukan berdasarkan laporan saja, yang tidak di cek kebenarannya." 22

Hal ini menunjukkan bahkan sebelum ada putusan MK itu pun kebenaran informasi yang ada di dalam akta kelahiran masih dapat dipertanyakan, dengan adanya putusan MK menambahkan beban kepada dispendukcapil.

Dari penjelasan di atas, pencatatan kelahiran sangat penting. Mulai dari instansi pemerintah yang bertanggung jawab untuk pencatatan kelahiran yang harus memverifikasi dokumen-dokumen yang dicatatkan dengan benar dan hati-hati, karena dokumen yang nantinya akan diterbitkan sebagai akta kelahiran, sangat menentukan kedudukan seorang anak. Dengan adanya akta kelahiran, maka identitas seorang anak menjadi jelas karena di dalam akta kelahiran tercatat informasiinformasi yang dasar tentang anak tersebut, seperti nama orang tua, tanggal lahir, dan di mana anak tersebut lahir. Dengan adanya informasi nama orang tua dari anak tersebut akan sangat menentukan

\footnotetext{
${ }^{22}$ Juswito Satrio. 1999. Hukum Pribadi Bagian I (persoon Alamiah), Bandung: Citra Aditya Bakti, Hlm.109.
} 
kedudukan anak tersebut dalam suatu keluarga, serta menentukan hak waris anak tersebut dalam keluarganya, selain itu juga menghindari adanya manipulasi, penipuan, eksploitasi anak, human trafficking yang marak terjadi pada anak-anak yang tidak mempunyai kejelasanan tentang identitas diri.

\section{Hak Untuk Mendapatkan Kepastian Hukum}

Dalam masalah pembatalan akta kelahiran anak, maka terdapat beberapa perubahan terhadap status dan kedudukannya. Kelahiran biasa dicatatkan dan didaftarkan menjadi akta kelahiran tepat setelah seorang anak lahir, pencatatan dan pendaftaran ini dapat dilakukan oleh orang tua dari anak yang lahir tersebut ataupun orang yang menemukan anak ini, hal ini membuktikan bahwa pencatatan kelahiran ini di luar dari kemampuan anak pada saat itu. Semua proses pencatatan dan pendaftaran kelahiran seorang anak tidak melibatkan anak ini, oleh karena itu sudah seharusnya anak ini mendapatkan perlindungan hukum terhadap hakhaknya.

Dalam hal orang dewasa dapat mengajukan gugatan ataupun permohonan pembatalan akta kelahiran, maka sebagai anak, apabila anak tersebut telah cukup umur atau dianggap dewasa menurut un- dang-undang untuk melakukan tindakan hukum, anak tersebut memiliki hak untuk mendapatkan kepastian hukum tentang status dan kedudukannya. Salah satu cara untuk mendapatkan kepastian hukum ini apabila anak ini yakin akan status dan kedudukannya dan merasa putusan atau penetapan yang diberikan oleh hakim pengadilan bukanlah hal yang benar dan adil, maka anak mempunyai hak untuk mengajukan upaya hukum yang berlaku dalam pengadilan.

Upaya untuk mendapatkan kepastian hukum terhadap kedudukan dan statusnya, maka perlu dipahami terdapat 2 macam gugatan yang dapat diajukan kepada pengadilan serta upaya hukum yang dapat dilakukan apabila terdapat kesalahan, yaitu: ${ }^{23}$

a. Gugatan Voluntair (permohonan)

Gugatan voluntair atau permohonan adalah permasalahan perdata yang diajukan dalam bentuk permohonan yang ditandatangani pemohon atau kuasanya yang ditujukan kepada Ketua Pengadilan Negeri. ${ }^{24}$ Hasil dari permohonan berupa penetapan, berisi pertimbangan dan diktum penyelesaian

\footnotetext{
${ }^{23}$ Moh. Taufik Makarao. 2004. Pokok-Pokok Hukum Acara Perdata, Jakarta: Rineka Cipta, Hlm. 16.

${ }^{24}$ Yahya Harahap. 2005. Hukum Acara Perdata, Jakarta: Sinar Grafika. HIm. 29.
} 
permohonan dituangkan dalam bentuk penetapan, biasa dapat disebut ketetapan. Dengan adanya penetapan dari hakim, maka penetapan tersebut merupakan produk yang diterbitkan hakim atau pengadilan dalam menyelesaikan permasalahan yang diajukan kepadanya, dengan sendirinya merupakan akta otentik, dengan kata lain penetapan atau putusan yang dijatuhkan pengadilan bernilai sebagai akta otentik. ${ }^{25}$ Nilai kekuatan pembuktian dari penetapan ini melekat terbatas pada diri pemohon, tidak melekat pada orang lain, oleh karena itu dalam penetapan tidak melekat ne bis en idem, sehingga setiap orang yang merasa dirugikan oleh penetapan itu, dapat mengajukan gugatan atau perlawanan olehnya. ${ }^{26}$

Dalam upaya hukum terhadap suatu permohonan, harus diingat bahwa penetapan atas permohonan adalah putusan tingkat pertama dan terakhir sehingga tidak dapat diajukan banding, maka upaya hukum yang dapat dilakukan adalah melalui kasasi, mengajukan perlawanan selama proses pemeriksaan berlangsung, peninjauan kembali, dan apabila upaya hukum lain

${ }^{25}$ Setiawan. 1992. Aneka Masalah Hukum dan Hukum Acara Perdata, Banudng: Alumni, Hlm. 399

${ }^{26}$ Yahya Harahap, Op.Cit, Hlm. 42 tidak dapat dilakukan, maka dapat mengajukan gugatan baru. ${ }^{27}$

b. Gugatan Contentiosa (gugatan biasa)

Gugatan contentiosa dimaksud dengan gugatan perdata dalam praktik, disebut sebagai gugatan contentiosa untuk membedakan dengan gugatan voluntair. Gugatan ini biasa disebut gugatan saja, Sudikno Mertokusumo juga menggunakan istilah gugatan, berupa tuntutan perdata tentang hak yang mengandung sengketa dengan pihak lain, R. Subekti juga mempergunakan sebutan gugatan dalam surat gugatan. ${ }^{28}$ Hasil dari gugatan berupa putusan sangat bervariasi, begitu pula dengan upaya hukum terhadap putusanputusan tersebut berbeda-beda tergantung dari karakteristik putusannya, sebagai berikut:

1. Putusan yang menolak seluruh gugatan

Hal ini dapat terjadi apabila bukti-bukti yang diajukan ke pengadilan oleh penggugat tidak dapat dibuktikan kebenarannya/ keautentikannya untuk mendukung dalil gugatannya di dalam persidangan dan gugatannya, ataupun alat bukti yang diajukan oleh tergugat dapat melumpuhkan alat bukti penggugat.

${ }^{27}$ Ibid, Hlm. 43-44.

${ }^{28}$ Ibid., HIm. 47. 
Mengingat bahwa perkara yang diputus dengan amar menolak gugatan dan berkekuatan tetap, maka dalam putusan ini meekat ne bis in idem seperti yang telah ditegaskan dalam BW pasal 1917, sehingga hasil dari putusan tersebut sudah final dan tidak dapat lagi diajukan gugatan baru untuk kali yang kedua. ${ }^{29}$ Upaya hukum yang dapat dilakukan adalah melalui upaya banding dan kasasi.

2. Putusan yang mengabulkan gugatan

Dalam putusan akhir yang mengabulkan gugatan penggugat, bahwa penggugat berhasil membuktikan dalil gugatan dan memberikan bukti yang otentik, sehingga cukup beralasan mengabulkan gugatan. Dalam putusan yang mengabulkan gugatan, bisa dikabulkan seluruhnya maupun sebagian, hal ini menjadi kewenangan hakim untuk mempertimbangkan dari sisi hukumnya. Upaya yang dapat dilakukan untuk ini adalah dengan mengajukan banding, kasasi, dan peninjauan kembali.

3. Putusan yang menyatakan gugatan tidak dapat diterima.

Dalam pernyataan hakim bahwa putusan tidak dapat diterima maka hakim pasti menemukan cacat formil yang terkandung dalam gugatan tersebut. Terdapat berbagai macam cacat formil yang dapat dijadikan dasar oleh hakim untuk menjatuhkan putusan yang menyatakan gugatan tidak dapat diterima, antara lain sebagai berikut ${ }^{30}$ :

a. Yang mengajukan gugatan adalah kuasa yang tidak didukung oleh surat kuasa khusus.

b. Error in persona

c. Gugatan di luar yuridiksi absolut atau relatif pengadilan

d. Obscuur libel

e. gugatan masih premature

f. gugatan telah daluwarsa

Upaya hukum yang dapat dilakukan adalah dengan memperbaiki gugatan tersebut agar tidak mengadung cacat formil kembali dan dapat mengajukan banding dan mengajukan gugatan baru.

Setiap orang yang mengajukan gugatan perlu untuk mengetahui putusan yang dikeluarkan berupa penetapan atau berupa putusan, karena terdapat perbedaan dalam upaya hukum yang dapat dilakukan untuk menindaklanjuti penetapan atau putusan, hal ini perlu diperhatikan untuk menghindari kesalahan formil pada saat

\footnotetext{
${ }^{30}$ Ibid., HIm. 888-891.
} 
pengajuan upaya hukum yang bersangku$\tan$.

\section{Hak Perlindungan Dari Negara}

Pada dasarnya hak dapat dibedakan menjadi 2 (dua) yaitu yang pertama, hak manusia (human rights) yaitu hak yang melekat pada manusia dan secara asasi ada sejak manusia itu dilahirkan. Hak ini biasa disebut Hak Asasi Manusia (selanjutnya disebut HAM) yang dijadikan sebagai asas undang-undang. Hak ini bersifat tetap dan utama tidak dapat dicabut dan tidak tergantung dengan ada atau tidaknya orang lain di sekitarnya. Kedua, hak undang-undang (legal rights) yaitu hak yang diberikan oleh undang-undang secara khusus kepada pribadi manusia, hak ini diberikan pengaturan dalam sejumlah perundang-undangan. ${ }^{31}$ Hak-hak manusia ini disebut hak asasi, karena dianggap sebagai dasar dan menjadi asasasas dalam undang-undang. Perlindungan terhadap hak asasi menjadi tanggung jawab negara untuk mengatur pelaksanaan hak asasi, mengatur pembatasan demi kepentingan umum, bangsa dan negara, selain itu tanggung jawab juga harus dipikul oleh segenap individu warga negara agar tidak terjadi kesewenang-

\footnotetext{
${ }^{31}$ H. Muladi. 2005. Hak Asasi Manusia Hakekat, Konsep, dan Implikasinya Dalam Perspektif Hukum dan Masyarakat, Bandung: Refika Aditama, Hlm. 229.
}

wenangan dalam pelaksanaan upaya perlindungan hak asasi ini.

Upaya perlindungan hak asasi oleh Indonesia dapat dilihat dengan pengakuan bahwa hak-hak asasi manusia bersifat universal, dimana Indonesia menjadi salah satu negara pihak yang ada dalam Deklarasi Wina tentang HAM dan instrumeninstrumen HAM internasional pada tahun 1993 yang menyatakan bahwa pelaksanaan tentang HAM merupakan wewenang dan tanggung jawab setiap pemerintah negara dengan memperhatikan sepenuhnya keanekaragaman tata nilai, sejarah, kebudayaan, sistem politik, tingkat pertumbuhan sosial dan ekonomi serta faktor-faktor lain yang dimiliki bangsa yang bersangkutan. Selain itu, di Indonesia juga tercantum perlindungan hak terhadap warga negaranya dalam UndangUndang Dasar 1945, Undang-Undang HAM, untuk perlindungan terhadap seseorang yang belum berusia 18 (delapan belas) tahun maka dilindungi pula dengan Undang-Undang Perlindungan anak.

Dengan adanya pembatalan akta kelahiran seseorang, yang pastinya berakibat pada status dan kedudukan orang tersebut, tidak berarti perlindungan hak oleh negara juga berubah. Perlindungan hak oleh negara kepada warga negara nya tidak melihat status dan kedudukannya, mes- 
kipun orang tersebut menjadi anak yang sah maupun anak luar kawin. Hal ini tidak berakibat pada perlindungan hak yang diberikan negara kepada orang tersebut. Hal ini ditegaskan di dalam UndangUndang Dasar 1945 dan juga di dalam Undang-Undang Perlindungan Anak. Perlindungan dari negara terhadap anak maupun dewasa terjamin dengan adanya undang-undang yang berlaku di Indonesia, perlindungan ini diberikan kepada setiap warga negara, oleh karena itu memiliki akta kelahiran sebagai bukti identitas serta Nomor Induk Kependudukan sangat diperlukan dalam hal negara harus memperhitungkan berapa besar biaya untuk perlindungan kepada warga negaranya.

\section{Kedudukan Anak Setelah Putusan Pembatalan Akta Kelahiran}

Keabsahan perkawinan sangat berpengaruh dalam kedudukan dan status anak dari pasangan tersebut, hal ini seringkali menjadi masalah di Indonesia sehingga menyebabkan banyak kasus tentang pembatalan akta kelahiran anak. Pembatalan berasal dari kata batal yang artinya tidak berlaku atau tidak sah, sedangkan pembatalan diartikan sebagai proses, cara, perbuatan membatalkan atau pernyataan batal. $^{32}$ Pembatalan yang dimaksud dalam pembahasan ini adalah pembatalan akta kelahiran, di mana akta kelahiran merupakan akta otentik yang berarti akta tersebut dibuat dalam bentuk yang ditentukan undang-undang dan dibuat oleh pejabat umum yang berwenang. Dari perngertian di atas maka dapat disimpulkan pembatalan akta kelahiran akta kelahiran adalah proses, cara, perbuatan membatalkan suatu akta yang dikeluarkan oleh pejabat umum yang berwenang, tidak ada penjelasan khusus mengenai pembatalan akta kelahiran ini.

Pembatalan akta kelahiran ini dilaksanakan dengan putusan pengadilan yang berkekuatan hukum tetap karena dalam suatu permohonan atau gugatan pembatalan akta kelahiran pasti ada pihak yang dirugikan, sehingga sebelum pembatalan tersebut terjadi, perlu diperiksa kembali alasan-alasan dan bukti yang dapat membatalkan akta kelahiran tersebut. Mengingat bahwa akta kelahiran menentukan identitas seseorang serta juga kepastian hukum terhadap kedudukan dan statusnya, maka hanya hakim pengadilan yang memiliki wewenang untuk menguji secara materiil pembatalan akta kelahiran. Hal ini menghindari adanya pemalsuan,

\footnotetext{
${ }^{32}$ Kamus Besar Bahasa Indonesia, batal, https://kbbi.web.id/batal, diakses pada tanggal 28 September 2017, jam 12.34 WIB
} 
eksploitasi anak, ataupun jual-beli anak yang ilegal.

Berdasarkan hasil penelitian tentang pembatalan akta kelahiran anak, status dan kedudukan anak akan berpengaruh setelah adanya putusan atau penetapan pengadilan yang berkekuatan hukum tetap. Saat putusan atau penetapan pengadilan menyatakan permohonan ataupun gugatan dikabulkan, maka akan terjadi perubahan status dan kedudukan bagi yang bersangkutan dalam akta kelahiran tersebut, beberapa perubahan kedudukan yang mungkin terjadi, yaitu dari anak sah menjadi anak luar kawin, anak luar kawin menjadi anak sah, anak sah menjadi bukan anak.

\section{Hak Alimentasi Antara Anak dan Orang Tua}

Alimentasi atau pemeliharaan anak adalah memberikan biaya pemeliharaan bagi anak dan pendidikan yang diperlukan anak yang masih kecil, baik laki-laki maupun perempuan atau yang sudah besar tetapi belum dewasa, menyediakan sesuatu yang menjadi kebaikannya, menjaganya dari sesuatu yang menyakiti dan berdiri sendiri menghadapi hidup dan memikul tanggung jawab. ${ }^{33}$

Hal ini biasa lebih dikenal dengan hak dan kewajiban antara anak dan orang tua, diatur di dalam Undang-Undang Perkawinan Pasal 45-49 Kewajiban pemeliharaan orang tua terhadap anak tetap akan tetap berlangsung hingga anak tersebut mencapai 18 (delapan belas) tahun atau belum pernah melangsungkan perkawinan, kecuali kekuasaan orang tua atas anaknya dicabut. Perlu dipahami bahwa dengan dicabutnya kekuasaan orang tua atas anaknya tidak berarti orang tua lepas dari kewajiban untuk memberi biaya pemeliharaan anak tersebut. Anak juga memiliki kewajiban untuk memelihara dan menghormati orang tuanya dan keluarga dalam garis lurus ke atas, hal ini akan timbul apabila anak tersebut telah dewasa, mampu untuk membantu dan memang keluarga dalam garis lurus ke atas tersebut memang benar-benar memelurkan bantuan.

Bahwa orang yang tidak berketiadaan lagi menuntut sekedar kewajiban hukum terhadap anaknya yang sudah dewasa untuk membantu orangtuanya dalam batas-batas kemampuan yang ada padan-

\footnotetext{
${ }^{33}$ Agen.(2015), "Pelaksaan Kewajiban Pemeliharaan Anak (alimentasi) Oleh Orang Tua Pasca Putusan Perceraian di Kabupaten Rokan Hilir", JOM Fakultas Hukum Universitas Riau Vol. II No. 1, Februari $2015: 2$
} 
ya, baik menyangkut perbelanjaan dan pemeliharaan kesehatan kepada orang tua yang bersangkutan. ${ }^{34}$

Dengan adanya pembatalan akta kelahiran, pasti juga berpengaruh terhadap kedudukan antara orang tua dan anak, hal ini juga pasti berkaitan dengan hak alimentasi. Pengaruh terhadap hak alimentasi ini tergantung pada putusan/ penetapan pengadilan, yaitu:

a. Anak sah menjadi anak luar kawin / anak luar kawin menjadi anak sah

Anak tersebut tetap memiliki hak alimentasi antara orang tua dengan dirinya, berupa kewajiban pemeliharaan dari orangtua terhadap anak, begitu pula sebaliknya. Dengan berubahnya status menjadi anak luar kawin atau anak sah, kewajiban antara orangtua dan anak ini tidak bisa hilang, hal ini tetap berlaku kecuali ada pencabutan kekuasaan orangtua terhadap anak yang diputuskan oleh pengadilan. Meskipun ada pencabutan kekuasaan, orang tua tetap berkewajiban memberi biaya pemeliharaan kepada anak tersebut.

b. Anak sah/anak luar kawin dibatalkan menjadi bukan anak

\footnotetext{
${ }^{34}$ Yahya Harahap. (1975). Hukum Perkawinan Nasional Berdasarkan UU No 1 Tahun 1974 dan Peraturan Pemerintah No 9 Tahun 1975, Medan: Zahir, Hlm. 214.
}

Kedudukan dari anak sah / anak luar kawin yang dibatalkan oleh putusan/ penetapan pengadilan menjadi bukan anak dari orangtua yang tercatat di dalam akta kelahirannya, maka secara langsung juga memutuskan hak alimentasi antara orang tua dengan anaknya, sehingga anak tidak bisa menuntut pemeliharaan kepada orangtuanya dan begitu pula sebaliknya.

Penjelasan di atas menegaskan bahwa hak alimentasi antara anak dan orang tua tidak dapat hilang selama bukti-bukti hubungan darah antara anak dan orang tua tersebut dapat dibuktikan kebenaran. Hak alimentasi tidak hanya semata tentang penafkahan hidup, namun juga menyangkut kewajiban untuk memelihara dan menghormati orang tua.

\section{PENUTUP}

\section{Kesimpulan}

Akta kelahiran merupakan bukti identitas diri anak serta perlindungan pertama yang dapat diberikan oleh negara, dokumen ini berkaitan dengan kepastian hukum dan kedudukan anak tersebut dalam suatu silsilah keluarga yang berpengaruh pada hak waris. Hal ini didasarkan pada Undang-Undang Perkawinan Pasal 55 dan Undang-Undang Perlindungan Anak Pasal 27 dan 28. Selain dia- 
tur dalam undang-undang yang ada di Indonesia, pentingnya catatan kelahiran juga diakui oleh negara-negara di luar melalui Convention On The Right of The Child, di mana ditegaskan bahwa negara-negara wajib melaksanakan hak anak berupa identitas, termasuk kewarganegaraan, nama dan hubungan kekeluargaan yang diakui oleh hukum.

Sebagai akibat dari pembatalan akta kelahiran, anak juga mempunyai hak untuk membela diri dengan upaya hukum yang dapai ia lakukan, tentunya juga melihat posisi anak dalam keadaan dewasa atau cukup umur, upaya hukum yang dapat dilakukan sesuai dengan jenis putusan yang dihadapi oleh anak. Selain itu, anak memiliki hak perlindungan dari negara, dimana negara melindungi dengan adanya Undang-Undang Dasar 1945 dan diatur lebih khusus dalam UndangUndang Hak Asasi Manusia dan UndangUndang Perlindungan Anak. Upaya perlindungan hak yang dilakukan oleh negara ini diberikan kepada setiap warga negara Indonesia tanpa diskriminasi apapun. Kedudukan anak dapat berubah akibat pembatalan akta kelahiran, dari anak sah menjadi anak luar kawin, anak luar kawin menjadi anak sah, bahkan dari anak sah menjadi bukan anak, hal ini jelas juga mempengaruhi hak waris dari anak terse- but. Pembatalan akta kelahiran juga berpengaruh pada hak alimentasi antara anak dan orang tua, di mana terdapat hubungan tanggung jawab antara anak dan orang tua yang memang mempunyai hubungan darah. Hak alimentasi antara anak dan orang tua tidak dapat hilang selama buktibukti hubungan darah antara anak dan orang tua tersebut dapat dibuktikan kebenaran.

\section{Saran}

1. Hendaknya ada proses pencatatan kelahiran yang prosesnya lebih mudah dan efektif bagi masyarakat yang tinggal di pedalaman yang untuk mencapai kota masih susah ditempuh. Keterlambatan pencatatan kelahiran yang lebih dari 1 tahun (setahun) sebaiknya tetap harus menggunakan penetapan pengadilan, mengingat banyak hal yang dapat terjadi dalam waktu 1 tahun (setahun), demi menghindari adanya pemalsuan juga penggelapan anak.

2. Perlu adanya peraturan lebih lanjut mengenai kedudukan anak luar kawin yang telah dijanjikan di UndangUndang Perkawinan Pasal 43 ayat (2), dimana sampai sekarang belum ada pelaksanaan tentang peraturan pemerintah yang mengatur tentang kedudukan anak luar kawin. Perlu adanya perbedaan yang jelas antara 
anak sah dan anak luar kawin sehingga tidak menjadi buram yang mengakibatkan makin banyaknya terjadi kelahiran anak di luar perkawinan yang sah.

\section{BIBLIOGRAFI}

\section{Buku}

Gosita, A. 1989. Masalah Perlindungan Anak. Jakarta: Akademi Pressindo.

Harahap, Y. 1975. Hukum Perkawinan Nasional Berdasarkan UU No. 1 Tahun 1974 dan peraturan Pemerintah No. 9 Tahun 1975. Medan: Zahir.

Harahap, Y. 2005. Hukum Acara Perdata. Jakarta: Sinar Grafika.

Makarao, Moh. Taufik. 2004. PokokPokok Hukum Acara Perdata, Jakarta: Rineka Cipta.

Marzuki, Peter Mahmud. 2010. Penelitian Hukum Cetakan ke VI, Jakarta: Kencana.

Muladi, H. 2005. Hak Asasi Manusia Hakekat, Konsep, dan Implikasinya Dalam Perspektif Hukum dan Masyarakat. Bandung: Refika Aditama.

Satrio, Juswito. 1999. Hukum Pribadi Bagian I (persoon Alamiah). Bandung: Citra Aditya Bakti.

Satrio, Juswito. 2000. Hukum Keluarga Kedudukan Anak Dalam Undang-
Undang. Bandung: Citra Aditya Adi.

Setiawan. 1992, Aneka Masalah Hukum dan Hukum Acara Perdata. Bandung: Alumni.

Situmorang, Victor M. dan Cormentyna Sitanggang. 1991. Aspek Hukum Akta Catatan Sipil Di Indonesia. Jakarta: Sinar Grafika.

Tutik, Titik Triwulan. 2006. Pengantar Hukum Perdata. Jakarta: Prestasi Pustaka.

Volmar. (1989).Pengantar Studi Hukum Perdata Jilid I. Jakarta: Rajawali

Waluyadi. 2009. Hukum Perlindungan Anak. Bandung: Mandar Maju.

\section{Hasil Penelitian}

Daly Erni. 1999. Kajian Implementasi Peraturan Perundang-undangan Dalam Hal Pembuatan Akta Kelahiran, Laporan Penelitian, Depok

\section{Jurnal}

Agen. 2015. 'Pelaksanaan Kewajiban Pemeliharaan Anak (alimentasi) Oleh Orang Tua Pasca Putusan Perceraian di Kabupaten Rokan Hilir' JOM Fakultas Hukum Universitas Riau, Vol. II No. 1, Februari.

Djumikasih. 2013. 'Implikasi Yuridis $\mathrm{Pu}-$ tusan MK Nomor 46/PUUVIII/2010 Terhadap Akta Kelahiran Anak Luar Kawin', Jurnal Arena 
Hukum Universitasi Brawijaya, Kementerian Koordinator Bidang PemVol.6 No.2, Agustus.

Trias Palupi Kurnianingrum. 2014. 'Implikasi Putusan Mahkamah Konstitusi No 18/PUU-XI/2013 Terhadap Penerbitan Akta Kelahiran' Jurnal Ilmiah Hukum Negara Hukum SETJEN DPR RI, Vol.5 no.1.

Rachmadi Usman. 2014. 'Prinsip Tanggung Jawab Orangtua Biologis Terhadap Anak Di Luar Perkawinan', Jurnal Konstitusi, Vol.11 no.1.

Sasmiar. 2012. 'Kedudukan Hukum Anak Tidak Sah Sebelum Dan Setelah Putusan Mahkamah Konstitusi Nomor 46/PUU-VIII/2010', Jurnal Ilmu Hukum Universitas Jambi, Vol.3 No.1, September.

\section{Internet}

Davit Setyawan, 'Pemenuhan Hak Atas Akta Kelahiran Merupakan Bagian Dari Hak Sipil Yang Harus Dilindungi Konstitusi' <http://www.kpai.go.id/artikel/peme nuhan-hak-anak-atas-akta-kelahiranmerupakan-bagian-dari-hak-sipilyang-harus-dilindungi-konstitusi> diakses tanggal 15 Agustus 2017

Kamus Besar Bahasa Indonesia, 'batal', https://kbbi.web.id/batal, diakses pada tanggal 28 September 2017

\section{Peraturan Perundang-undangan}

Undang-Undang Republik Indonesia Nomor 1 tahun 1974 tentang Perkawinan, Lembaran Negara Republik Indonesia Tahun 1974 Nomor 1 dan Tambahan Lembaran Negara Republik Indonesia Nomor 3019

Undang-Undang Republik Indonesia Nomor 39 tahun 1999 tentang Hak Asasi Manusia, Lembaran Negara Republik Indonesia Tahun 1999 
Nomor 165 dan Tambahan Lembaran Negara Republik Indoensia Nomor 3886

Undang-Undang Republik Indonesia Nomor 24 tahun 2013 tentang Perubahan atas Undang-Undang Nomor 23 tahun 2006 tentang Administrasi Kependudukan, Lembaran Negara Republik Indonesia Tahun 2013 Nomor 232 dan Tambahan Lembaran Negara Republik Indonesia Nomor 5475

Undang-Undang Nomor 17 tahun 2016 tentang Penetapan Peraturan Pemerintah Pengganti UndangUndang Nomor 1 Tahun 2016 Tentang Perubahan Kedua Atas Undang-Undang Nomor 23 Tahun 2002 Tentang Perlindungan Anak
Menjadi Undang-Undang, Lembaran Negara Republik Indonesia Tahun 2016 Nomor 237 dan Tambahan Lemabaran Negara Republik Indonesia Nomor 5946

\section{Putusan Pengadilan}

Putusan Mahkamah Konstitusi Nomor 46/PUU-VIII/2010 tentang Pengujian Pencatatan Perkawinan dan Status Hukum Anak Yang Dilahirkan Dari Perkawinan Yang Tidak Tercatatat Undang-Undang Nomor 1 Tahun 1974 Tentang Perkawinan

Putusan Mahkamah Konstitusi Nomor 18/PUU-XI/2013 tentang Pengujian Undang-Undang Nomor 23 Tahun 2006 Tentang Administrasi Kependudukan (Pasal 32 ayat (2)) 